\title{
Rural Farm Households and Forest Land Use Change in Nigeria: A Primary Siamese Twins?
}

\section{Adetoye AM*}

University of Agriculture, Abeokuta · Department of Agricultural Economics and Farm Management, Nigeria

\section{Short Communication}

Volume 2 Issue 4

Received Date: May 28, 2018

Published Date: June 18, 2018

DOI: $10.23880 /$ jenr-16000135

*Corresponding author: Ayoade Mathew, Adetoye, University of Agriculture, Abeokuta, Department of Agricultural Economics and Farm Management, Nigeria, Email: adetoyeam@funaab.edu.ng

\section{Abstract}

Although more of forest land has been converted to cultivated land among rural farm households in many developing countries however, the primary cause of change is yet to be fully understood. Thus, the reason why many policies developed to curtail the damage has failed. The paper proposed the need to carefully investigate the main primary cause of forest land use change through a detailed approach, to enable policy makers understand the right approach to ensure forest conservation. This will help to understand how, and the extent to which farm households contributes to forest land use change other than considering them as the primary agent particularly, in Nigeria.

Keywords: Land use; Forest; Rural farming; Nigeria

\section{Short Communication}

Over the years, people have lived within and around forest. In most tropical regions of the world with Nigeria inclusive, human settlements, especially the rural households strongly depend on forest and forestland for survival [1,2]. Greengrass [3] observed that most of the households living within the forest communities are farmers, and timber workers, and their livelihood depend solely on forests and its resources. Worst still, illiteracy and poverty level of rural households within forest communities are very high, and these contribute to the level of unhealthy forest land use practices among them [4].
Several studies have identified different drivers of forestland use change [5-13]. While there are several drivers of forest land use change, some (agriculture, timber/logging, fuelwood) are considered as primary agents. While others (like mining, urbanization, uncontrolled fire and grazing) are considered as secondary drivers [13-15]. The primary drivers are considered to usually initiate land use change for other drivers to effect the further change, even though such change might be permanent or possibly greater than the initial change. This explains reasons why more attention is given to primary drivers when discussing forestland use change [16-20]. 
It has been established that forestland use change in Nigeria is caused mainly by rural farming activities following their strong dependency on forestland $[7,9,21,11,22]$. Several studies affirm that rural farmers (more than 20 million) practice shifting cultivation where by each farmer cultivates a plot of land for two to three years after which soil fertility is depleted and he moves to another plot to allow the previous plot to fallow and recuperate [22,4]. The tendency is for farmers to look for a virgin forestland where soils are relatively more fertile. This causes more deforestation and depletion of forest resources [21]. Another important fact justifying such claims is that most forest reserves are dominated by more of cultivated land $[10,23,24]$.

Even though rural farm households are considered agent of deforestation through shifting cultivation practices, it might be of interest to know if there are preoccurrent event on such forestland before the emergence and the dominance of farm households' activities like farming and fuelwood collection. If such pre-occurrence event exists, rural farm households should not to be considered as the primary agent influencing forest land use change. Likewise, they are not to be firstly considered when implementing policy that will ensure positive forest land use change if at all such policy is to prosper.

Further this need, UNFCCC, [25] encourages developing countries to further investigate, identify. and describe clearly, activities and drivers of forest land use change. The demand stresses the need to consider critically how rural farm households do gain access and effect change on forestland. Inability to affirm the genesis of forest land use change particularly among rural farm households have contributed to failure in the implementation of effective forestland use policy in Nigeria. Recently, the forestry component of the National Agricultural Policy prescribes an increase from its present level of $10 \%$ of total land area to $20 \%$ but this has been elusive. This is already happening.

Hence, there is the need to establish how farm households (considered the main agent) do gain access and dominate forestland and possibly determine factors influencing such land use decisions. It will be of importance to know either farm households cultivate open forest lands, or they convert untapped forestland to farm land. Such information would help to guide in implementing effective forestland use policy in Nigeria. Similarly, the trend of forest land use change pattern could help investigate the relationship between farmers and the existed change on forestland. This can be achieved using satellite remote sensing. The tool allows for better tracking of deforestation and forest degradation events, types, and the causative activity [26,27]. Thus, while household survey data might be required to examine forestland use pattern and factors influencing such land use decisions, a spatial pattern of land use change, types and causative activity can be assessed or established using satellite imageries. The result from these two methods should facilitate a detailed knowledge of how unhealthy forest land use change is being initiated, and the right approach to curtail the change.

\section{References}

1. FAO (2003) Forestry Outlook Study for Africa: Regional Report - Opportunities and Challenges towards 2020. Food and Agriculture Organization Forestry Paper 141.

2. Adetoye AM, Okojie LO, Akerele D (2017) Agroforestry Practices and Carbon Sequestration Cost Estimates among Forest Land Dependent Households in Nigeria: A Choice Modelling Approach. J Earth Sci \& Clim Change 8(10): 417.

3. Greengrass EJ (2006) A Survey of Chimpanzees in South-west Nigeria. NCF-WCS Biodiversity Research Programme.

4. Borokini TI, Babalola FD, Amusa TO, Ivande ST, Wala ZJ, et al. (2012) Community-based Forest Resources Management in Nigeria: Case study of Ngel Nyaki Forest Reserve, Mambilla Plateau, Taraba State, Nigeria. J Tropical Forestry Environ 2(1): 69-76.

5. Raintree JB, Lundgren B (1985) Agroforestry potential for biomass production in integrated land use systems: Symposium on Biomass Energy systems: Building Blocks for sustainable Agriculture, Washington, World Resources Institute, 221.

6. FORMECU (1999) Forest Resources Study. Revised Forest Management Plan of Edo State 126.

7. Park CC (2002) Tropical Rainforest. London Routledge.

8. Anthony GB (2003) The Potentials of Erwin Adult, Education in Stopping the Problem of Deforestation in Cross River State. A Master Thesis. Dept. of Adult \& Non-formal Education Uniport Nov. 2005.

9. Sharma MP (2004) Managing the world's forests: looking for Balance between conservation and Development: IOWA: Kendeu/Hunt, USA. 
10. Cunningham WP, Cunningham MA (2004) Principles of Environmental science: inquiry and application. $2^{\text {nd }}$ (Ed.), New York: McGraw-Hill.

11. Tyani M (2007) Society and sustainable management of Natural Ecosystems. Proceedings of International Conferences on forest Society and sustainable Development, Casablanca, Morocco, pp: 19-21.

12. Olujobi OJ, Arooyemi L, Ogunyemi OO (2006) Sociocultural and institutional factor Affecting the Adoption of Agroforestry in Ondo State, Nigeria, In: Popoola L, Mfon P, Oni PI (Eds.), sustainable forest management in Nigeria: Lessons and prospects, proceedings of the 31st Annual Conference of the Forest Association of Nigeria Held in Markudi, pp: 316-323.

13. Hosonuma N, Herold M, De Sy V, De Fries RS, Brochaus M, et al. (2012) An Assessment of Deforestation and forest Degradation drivers in Developing Countries. Environ Res Lett 7(4): 4009.

14. Southgate D, Pearce D (1988) Agricultural Colonization and Environmental Degradation in Frontier Developing Economics. World Bank Environment Department Working Paper. No.9. Washington, DC: The World Bank.

15. FAO (2009) Forest Resource Situation in Nigeria. Food and Agriculture Organization, Forest Resources Main Report 2: 5-9.

16. Davies MW (1993) Community and private forest division. Napal: Department of forestry.

17. Anija-Obi FN (2001) Fundamentals of Environmental Education and Management. Calabar: University of Calabar press, Calabar- Nigeria.

18. Usang NM (2006) Influence of Traditional Beliefs on conservation of Natural Resources in Cross River Central. University of Calabar, Calabar. Unpublished M.Ed thesis.

19. Chokor BA (1993) Environment and Tourism in Nigeria - Lagos: Environment \& Behaviour Association of Nigeria.
20. Ibor OI, Abi EA (2005) Community Forest Management in the Tropical Moist Forest of Nigeria: The Cross-river State Experience in Popoola, et al., Sustainable Forest Management in Nigeria: Lesson \& Prospects Proceedings of the 30th Annual Conference of the Forestry Association of Nigeria held in Kaduna, Kaduna State, Nigeria 7.

21. NPF (2006) Approved National Forest Policy Document, Abuja.

22. Adekunle VAJ, Okunlola JO, Oke DO (2011) Management of Forest Ecosystems for Food Security and Rural Livelihoods in Southwest, Nigeria. Final Project Report for Global Change System for Analysis, Research and Training 2.

23. Nwoboshi LC (1987) Regeneration success of Natural Management Enriches planting and plantations of Nature species in West Africa. In: Mergen F, Vincent JR (Eds.), Natural management of tropical moist forest (92-136) Connecticut, Yale University Press.

24. Ajake AO (2008) Exploitation and management of forest resources in Cross River State. Unpublished PhD Thesis, University of Nigeria, Nsukka.

25. UNFCC (2010) Outcomes of the Work of the Ad hoc Working Group on Long-term Cooperative Action under the Convention-policy Approaches and Positive Incentives on Issues Relating to Reducing Emissions from Deforestation and Forest Degradation in Developing Countries: and the Role of Conservation, Sustainable Management of Forests and Enhancement of Forest Carbon Stock in Developing Countries. UNFCC COP 16 Cancun.

26. Hansen MC, Stehman SV, Potapov PV (2010) Quantification of global gross forest cover loss. Proc Natl Acad Sci 107(19): 8650-8655.

27. Gibbs HK, Ruesch AS, Achard F, Clayton MK, Holmgren P, et al. (2010) Tropical forests were the primary sources of new agricultural land in the 1980s and 1990s. Proc Natl Acad Sci 107(38): 16732-16737.

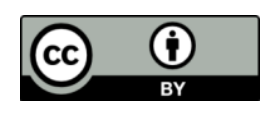

